\title{
IGF-1 modulates gene expression of proteins involved in inflammation, cytoskeleton, and liver architecture
}

\author{
VJ Lara-Diaz ${ }^{1}$ - I Castilla-Cortazar ${ }^{1,2}$ - I Martín-Estal ${ }^{1}$ • M García-Magariño ${ }^{1}$ • \\ GA Aguirre ${ }^{1} \cdot$ JE Puche $^{3} \cdot$ RG de la Garza ${ }^{1} \cdot$ LA Morales $^{1} \cdot$ U Muñoz $^{3}$
}

Received: 18 April 2016 / Accepted: 16 December 2016/Published online: 26 January 2017

(C) The Author(s) 2017. This article is published with open access at Springerlink.com

\begin{abstract}
Even though the liver synthesizes most of circulating IGF-1, it lacks its receptor under physiological conditions. However, according to previous studies, a damaged liver expresses the receptor. For this reason, herein, we examine hepatic histology and expression of genes encoding proteins of the cytoskeleton, extracellular matrix, and cell-cell molecules and inflammation-related proteins. A partial IGF1 deficiency murine model was used to investigate IGF-1's effects on liver by comparing wild-type controls, heterozygous igfl $^{+/-}$, and heterozygous mice treated with IGF-1 for 10 days. Histology, microarray for mRNA gene expression, RT-qPCR, and lipid peroxidation were assessed. Microarray analyses revealed significant underexpression of igfl in heterozygous mice compared to control mice, restoring normal liver expression after treatment, which then normalized its circulating levels. IGF-1 receptor mRNA was overexpressed in $\mathrm{Hz}$ mice liver, while treated mice displayed a similar expression to that of the controls. Heterozygous mice showed overexpression of several genes encoding proteins related to inflammatory and acute-phase proteins and underexpression
\end{abstract}

Lara-Diaz VJ and Castilla-Cortázar I contributed equally to this work

Electronic supplementary material The online version of this article (doi:10.1007/s13105-016-0545-x) contains supplementary material, which is available to authorized users.

I Castilla-Cortazar

iccortazar@itesm.mx

1 Escuela de Medicina, Tecnologico de Monterrey, Avenida Morones Prieto No. 3000 Pte. Col. Los Doctores, 64710 Monterrey, Nuevo León, Mexico

2 Fundacion de Investigacion HM Hospitales, Madrid, Spain

3 Department of Medical Physiology, School of Medicine, Universidad San Pablo-CEU, Madrid, Spain or overexpression of genes which coded for extracellular matrix, cytoskeleton, and cell junction components. Histology revealed an altered hepatic architecture. In addition, liver oxidative damage was found increased in the heterozygous group. The mere IGF-1 partial deficiency is associated with relevant alterations of the hepatic architecture and expression of genes involved in cytoskeleton, hepatocyte polarity, cell junctions, and extracellular matrix proteins. Moreover, it induces hepatic expression of the IGF-1 receptor and elevated acute-phase and inflammation mediators, which all resulted in liver oxidative damage.

Keywords IGF-1 · Gene expression · Cytoskeleton · Tight junctions $\cdot$ Hepatocytes $\cdot$ Extracellular matrix

$\begin{array}{ll}\text { Abbreviations } \\ A N O V A & \text { Analysis of variance } \\ C C l_{4} & \text { Tetrachloride } \\ C T & \text { cycle threshold } \\ E C M & \text { Extracellular matrix } \\ E L I S A & \text { Enzyme-linked immunosorbent assay } \\ G H & \text { Growth hormone } \\ H C l & \text { Hydrochloric acid } \\ H \& E & \text { Hematoxylin and Eosin } \\ H L A & \text { Human leucocyte antigen } \\ H z & \text { Heterozygous (igf- } 1^{+/} \text {) } \\ I G F B P S & \text { IGF-1 binding proteins } \\ I G F-1 & \text { Insulin-like growth factor-1 } \\ I G F-1 R & \text { IGF-1 receptor } \\ I U G R & \text { intrauterine growth restriction } \\ M D A & \text { Malondialdehyde } \\ M M P S & \text { Metalloproteinases } \\ m R N A & \text { Messenger ribonucleic acid } \\ P B S & \text { Phosphate buffer saline }\end{array}$




\begin{tabular}{|c|c|}
\hline$P C R$ & Polymerase chain reaction \\
\hline RT-qPCR & $\begin{array}{l}\text { Real-time quantitative polymerase } \\
\text { chain reaction }\end{array}$ \\
\hline SEM & Standard error of mean \\
\hline SPSS & Statistical Package for the Social Sciences \\
\hline$G F \beta$ & Transforming growth factor $\beta$ \\
\hline & Wild-type, control group \\
\hline
\end{tabular}

\section{Introduction}

The liver is the main source of circulating insulin-like growth factor-1 (IGF-1) (more than 75\%). It is produced following growth hormone $(\mathrm{GH})$ endocrine stimulus. IGF-1 is a 70amino acid hormone with effects on almost every tissue and organ [27-29]. However, the liver is not a target organ for this hormone as liver cells do not express the receptor under physiological conditions. Additionally, exceptions to this are hepatic regeneration (when injury to the organ has occurred), fetal liver, and malignant transformation of the cells (i.e., when cells become tumorous) $[3,29,33,34,50]$.

Pituitary-secreted GH and liver-produced IGF-1 establish a negative feedback mechanism to maintain a controlled $\mathrm{GH} /$ IGF-1 axis [2, 7]. Circulating IGF-1 can be found in its biologically active free form; it is however mainly bound to proteins (IGF-1 binding proteins, IGFBPs), especially to IGFBP3 [24] to prolong their half-life from minutes to hours. Since IGF-1 has a wide range of physiological roles, its activity must be strictly controlled, where IGFBPs play their part. These binding proteins also help to modulate the interaction between IGF-1 and its receptor (IGF-1R), thereby indirectly controlling IGF-1 biological activity [15]. Moreover, IGFBPs possess IGF-1-independent actions mediated by their own membrane or intracellular receptors [15].

The variety of IGF-1 activities can be partly summarized as cell proliferation and differentiation; tissue growth and development; insulin-like activity; anti-inflammatory; and antioxidant, mitochondrial protection, and prosurvival/antiaging. Moreover, its deficiency has been initially related to different pathologies, such as Laron's syndrome, intrauterine growth restriction (IUGR), liver cirrhosis, metabolic syndrome, and aging-related disorders, among others [22, 24, 28, 32, 38, 42, 43, 47, 49].

Referring to chronic liver disease, it has been intimately related to IGF-1 deficiency since the late $80 \mathrm{~s}$, and this idea has been consolidated over the following years. Decreased levels of free IGF-1 have been observed in patients with chronic liver disease, despite the normal or elevated GH secretion $[12,48]$. A wide series of murine experimental studies in $\mathrm{CCl}_{4}$-induced cirrhosis showed that low doses of IGF-1 were able to (1) improve liver function, cholestasis, histopathology, and liver architecture, reducing oxidative damage [4, $21,35]$; (2) restore mitochondrial dysfunction, increasing mitochondrial membrane potential and ATP synthesis and diminishing intramitochondrial free radical production [4, 40]; (3) normalize intestinal absorption of sugars and amino acids in both compensated cirrhosis and cirrhosis with ascites, acting on enterocyte cytoskeleton [5, 9, 39]; and (4) improve osteopenia, increasing bone mass [13, 14], and improve testicular atrophy and steroidogenesis (all closely related alterations in hepatic disease), recovering testicular-blood-barrier integrity $[6,8,11]$. Additionally, one clinical trial in patients with cirrhosis of different etiologies demonstrated a significant increase of albumin serum levels when administered IGF1 [17]. Furthermore, another murine study of $\mathrm{CCl}_{4}$-inducedcirrhosis suggested that IGF-1 treatment improves the polarity of hepatocytes and intercellular unions, leading to an improvement of liver architecture [45]. Bringing all these results together, it seems that the damaged liver could become a target organ for IGF-1 and thereby expressing the IGF-1 receptor. On the other hand, a specific and not well-understood IGF-1 activity might consist of contributing to cell polarity, acting on cytoskeleton $[5,11]$ and maintaining the normal hepatic architecture $[4,45]$.

In order to explore these possibilities, we conducted the present protocol using an experimental model of partial IGF1-deficient mice [45] in which heterozygous $i g f 1^{+-}$were employed as null mice are not viable and because a partial IGF-1 deficiency resembles the human pathology. In this work, we examine liver histopathology and hepatic expression of genes encoding proteins of cytoskeleton, tight junctions, desmosomes, and extracellular matrix, as well as its regulators - gene-encoding metalloproteases (MMPs). Additionally, we extended our study by analyzing liver expression of genes encoding IGF-1, IGF-1R, and proteins involved in inflammatory and acute phase response.

\section{Materials and methods}

\section{Animals and experimental design}

The experimental model was established and characterized as previously reported by our group [10]. Briefly, IGF-1 heterozygous mice $(\mathrm{Hz})$ were obtained by crossbreeding transgenic mice line $129 \mathrm{SV}^{\mathrm{igfl} \operatorname{tm} 1 \mathrm{Arge}}$ and MF1 non-consanguineous strain [30].

Animal genotype determination was performed by PCR analysis (Applied Biosystems, 2720 Thermal Cycler, Spain). DNA was extracted from a piece of tail, and specific primers were used to identify both $i g f-1$ and neo genes (Extract-NAmp TM Tissue PCR KIT Sigma, USA).

Animals were housed in cages inside a room with a 12-h light/dark cycle and constant humidity (50-55\%) and temperature $\left(20-22{ }^{\circ} \mathrm{C}\right)$. Food (Teklad Global $18 \%$ protein rodent diet, Harlan Laboratories, Spain) and water were given ad 
libitum. All experimental procedures were performed in compliance with the Guiding Principles for Research Involving Animals from the European Communities Council Directive of 24 November 1986 (86/609/EEC) and approved by the San Pablo-CEU University (Madrid) Bioethical Committee.

Three groups of $25 \pm 2$-week-old male mice were included in the experimental protocol: controls, wild-type mice (WT, igf $\left.-1^{+/+}, n=10\right)$; untreated heterozygous mice $\left(\mathrm{Hz}\right.$, igf $-1^{+/}$, $n=10$ ); and heterozygous mice subcutaneously treated with low IGF-1 doses of $20 \mu \mathrm{g} / \mathrm{kg} /$ day for 10 days (Hz + IGF-1, igf- $1^{+/-}, n=10$. We estimate this as a "low dose" compared to average doses commonly used which range from 80 to $4 \mathrm{mg} / \mathrm{kg}$ /day for weeks or months. Both WT and Hz groups received the administration vehicle in parallel, during the 10 days of treatment period. Chiron Corporation, USA, provided IGF-1.

On the 11th day, mice were weighed out and blood was extracted from the submandibular vein, and thereafter, the animals were sacrificed by cervical dislocation. The liver was carefully dissected out and divided into three sections: the left lobe was stored in RNAlater (Qiagen-Izasa, Spain) at $-80{ }^{\circ} \mathrm{C}$ for microarray and PCR genetic analyses; the first half-right lobe was fixed in $4 \%$ paraformaldehyde for histological studies; and the second half-right lobe was placed in cryotubes and subsequently snap-frozen by submerging in liquid nitrogen and stored at $-80{ }^{\circ} \mathrm{C}$ for posterior oxidative damage determinations.

\section{Serum IGF-1 concentrations and liver lipid peroxidation measurement}

Serum IGF-1 levels were determined by ELISA method in a Varioskan spectrophotometer (Thermo Scientific, Spain) and interpreted using Skanlt ${ }^{\circ}$ software, following specific commercial assay protocol instructions (Chiron Corporation, USA).

Malondialdehyde (MDA), widely used as an index of lipid peroxidation, was measured. N-methyl-2-phenylindole forms a stable chromophore with MDA at $45^{\circ} \mathrm{C}$ for $60 \mathrm{~min}$ in $37 \%$ $(12 \mathrm{~N})$ hydrochloric acid medium. MDA from tissue homogenates was then quantified by colorimetric assay at $586 \mathrm{~nm}$ (Hitachi U2000 Spectro; Boehringer Mannheim) using the available commercial kit Oxis LPO-586 (Bioxytech; OXIS International Inc., Portland, OR, USA). MDA concentrations were then determined extrapolating against a standard curve. Determinations were performed in liver tissue homogenates embedded in Tris- $\mathrm{HCl}$ solution $(1 \mathrm{~g}$ of liver tissue per $10 \mathrm{ml})$ centrifuged at $3000 \times g$ for $10 \mathrm{~min}$ at $4{ }^{\circ} \mathrm{C}$.

\section{Histological analysis}

Right liver lobe longitudinal sections were stained with $\mathrm{H} \& \mathrm{E}$ and Masson's trichrome (4 $\mu \mathrm{m}$ thick, Reichert-Jung 2030
Biocut Microtome, Leica Microsystems, Germany). Tissue analyses and descriptions were made in three different areas from each sample double blinded by two different observers using a light microscope (Leica, Switzerland).

\section{Gene expression studies}

\section{Microarrays analysis}

Liver mRNA was isolated from animals belonging to the three experimental groups in accordance with the protocol outlined in RNAqueousH-Micro Kit (Ambion, USA). Technical procedures for microarray analysis, including quality control of mRNA, labeling, hybridization, and scanning of the arrays, were performed according to standard operating procedures for Affymetrix protocols (GeneChipH Expression Analysis Manual, Affymetrix, USA). The mRNAs were profiled using Affymetrix HT MG-430. The array signals were normalized using Robust Multichip Averages [25], and batch effects of the three replicates were corrected using ComBat [26]. Differentially expressed genes between $\mathrm{Hz}$ vs. WT and $\mathrm{Hz}+\mathrm{IGF}-1$ vs. Hz samples were selected using FDRcorrected $p$ value of 0.01 ( $p$ value of $<0.05$ ).

\section{Total RNA extraction, reverse transcription, and RT-qPCR}

The left hepatic lobe was included in RNAlater (Qiagen-Izasa, Spain). PCR assays were performed on samples of conserved tissue, which were homogenized with TRIzol reagent (Invitrogen, UK) by Tissue Lyser LT (Qiagen-Izasa, Spain), and RNA was extracted and purified using the RNeasy Mini Kit (Qiagen-Izasa, Spain) including digestion with RNasefree DNase, according to the manufacturer's instructions. RNA quality was verified by the A260/A280 ratio and with the Bioanalyzer 2100 (Agilent Technologies Inc., USA). Purified RNA was then converted to cDNA by using the RNA-to-DNA EcoDryTM Premix (Clonetech Labs, USA) for q-PCR assays. Quantitative real-time PCR assays were performed in a 3100 Avant Genetic Analyzer (Applied Biosystems Hispania, Spain). The thermal profile consisted of an initial 5-min melting step at $95^{\circ} \mathrm{C}$ followed by 40 cycles at $95^{\circ} \mathrm{C}$ for $10 \mathrm{~s}$ and $60^{\circ} \mathrm{C}$ for $60 \mathrm{~s}$.

Specific Taqman ${ }^{\circledR}$ probes for the selected genes (actb, aifl, clqa, clqb, cat, ccl6, ccr5, cdh1, cdh5, cldn1, cldn14, cldn7, csf1r, ctgf, dsc2, gadd45a, grb2, igf1, igf1r, il10rb, jam2, jun, fos, ly96, lyz2, mark2, myolb, nras, pck1, pdk4, saa1, spna2, stk11, tubb2a, vcl, vim) were supplied by Applied Biosytems.

The relative mRNA expression levels of the genes of interest were normalized to Tbp expression using the simplified comparative threshold cycle delta, cycle threshold (CT) method $\left[2^{-(\Delta \mathrm{CT} \text { gene of interest }-\Delta \mathrm{CT} \text { actin })}\right][31]$. 


\section{Statistical analysis}

All data represent mean \pm SEM. Statistical analysis was performed on SPSS v22, (Statistical Package for the Social Sciences, USA). Significance was estimated by analysis of variance (ANOVA), followed by post hoc analysis. When appropriate, a confirmatory $t$ test for comparison between means of specific variable pairs was undertaken. Correlation between IGF-1 and weight was analyzed by Pearson's test. Differences were considered significant at a level of $p<0.05$.

\section{Results}

\section{Significant correlation between serum levels of IGF-1 and body weight}

Circulating levels of IGF-1 were statistically lower in the untreated $\mathrm{Hz}$ group when compared to the WT group $(\mathrm{Hz}$ $534.1 \pm 52.4 \mathrm{ng} / \mathrm{mL}$ and WT $696.1 \pm 59.2 \mathrm{ng} / \mathrm{mL}, p<0.01)$. Moreover, the Hz + IGF-1 group showed an increase of IGF-1 levels as compared to the $\mathrm{Hz}$ group $(681.3 \pm 7.7 \mathrm{ng} / \mathrm{mL}$, $p<0.01$ ), reaching similar values when compared to controls (WT). Therefore, low doses of IGF-1 therapy managed to normalize serum levels of IGF-1 in Hz mice.

With regard to body weight, a significant reduction was found in the untreated $\mathrm{Hz}$ group $(\mathrm{Hz}, 33.6 \pm 0.4 \mathrm{~g})$ compared to controls (WT, $40.1 \pm 1.2 \mathrm{~g}$, vs. Hz $p<0.001$ ). However, treatment was able to bring up the weight to normal values as no difference was observed among treated $\mathrm{Hz}$ animals as compared to controls $(\mathrm{Hz}+\mathrm{IGF}-1,39.6 \pm 0.8 \mathrm{~g}$, vs. WT not significant; vs. Hz $p<0.01)$. A direct and significant correlation was observed between circulating IGF-1 levels and body weights (Pearson's r 0.78, $p<0.001$ ).

\section{Histological study}

The conventional histological study of the liver tissue, stained with $\mathrm{H} \& \mathrm{E}$, revealed an altered hepatic architecture in the $\mathrm{Hz}$ group. In contrast to WT animals, in which liver architecture and unions between hepatocytes are preserved (see Fig. 1a), $\mathrm{Hz}$ mice show clumps of cells because of defective unions between hepatocytes disturbing sinusoidal spaces (see Fig. 1a) and their relation with the centrilobular vein. Moreover, nuclei in the WT group seem to be properly stabilized and polarized while on the $\mathrm{Hz}$ group, some cells seem to be enucleated and most of nucleus appears aberrant, suggesting apoptotic cells. Also, abundant vacuolization can be seen in the $\mathrm{Hz}$ animals where the WT do not present any, reaffirming the idea of apoptotic cells. According to cell shape, when examining the WT group, it can be readily perceived a proper polyhedral shape compared to a more rounded shape of the Hz hepatocytes. All of this suggests an apparent disruption of cell polarity, which will be further discussed relating such alterations with the cytoskeletal disturbances found. Masson's trichrome (Fig. 1b) confirms such
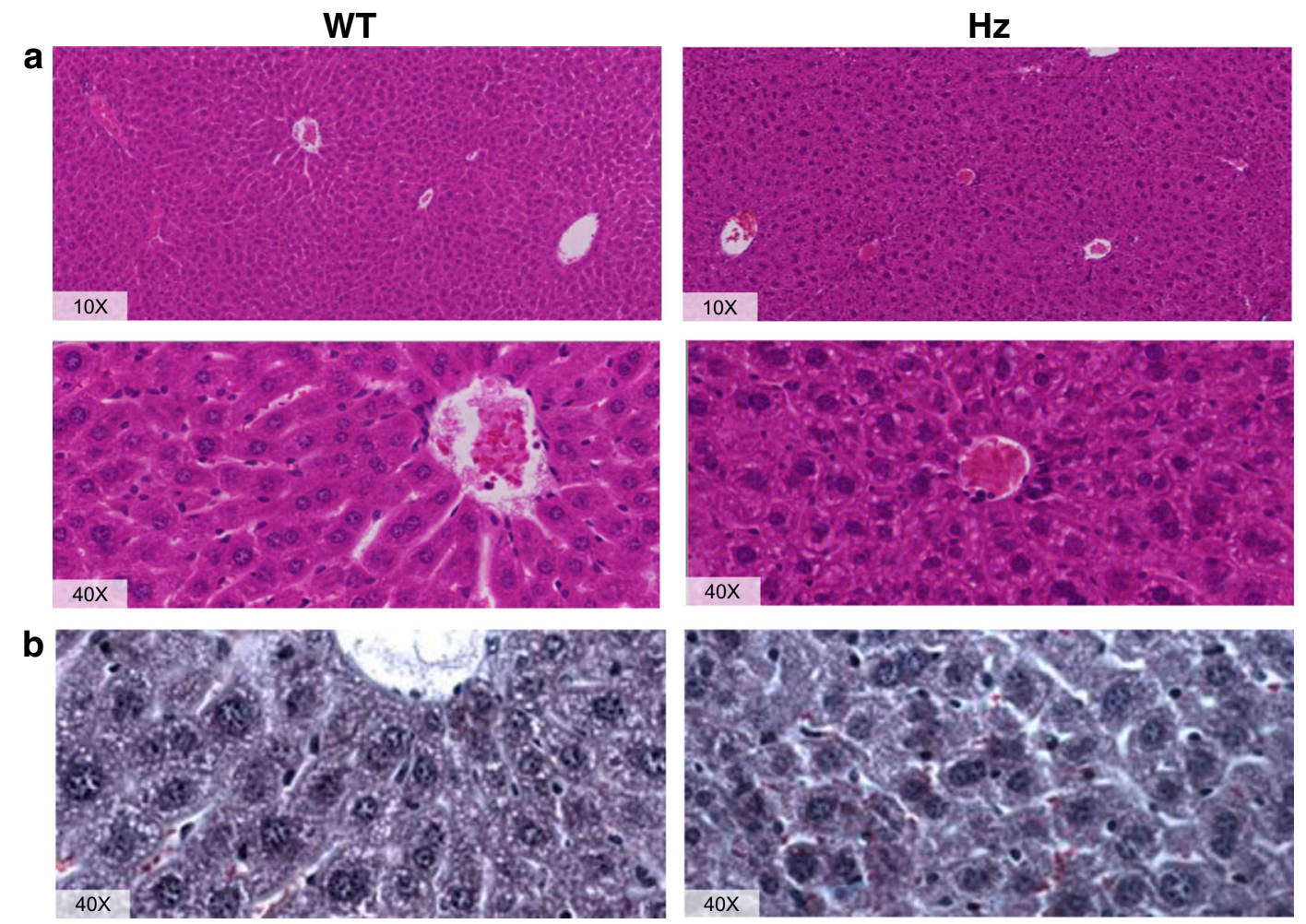

Fig. 1 Histology: a H\&E and b Masson's trichrome staining of liver sections from both, WT (left) and Hz (right) animals 
misalignments, and although no centrilobular vein appears in the preparation, it can be found that red blood cells (stained in red) flow through sinusoidal spaces in WT animals, whereas in $\mathrm{Hz}$, they do not follow any particular order. Masson's staining also reveals no fibrosis, consistent with the fact that no external or chemical insult was applied to these animals.

\section{Liver gene expression studies}

Microarray technology allowed us to identify about 120 genes which exhibit a fold change over \pm 1.5 in $\mathrm{Hz}$ as compared to WT mice, as well as Hz + IGF-1 compared to WT animals, all such genes being relevant to the purpose of this work.

\section{Gene expression of IGF-1 and its receptor}

As illustrated by Fig. 2a, a significant underexpression of igfl was found in $\mathrm{Hz}$ as compared to control group (WT). Low doses of IGF-1 were able to restore normal liver expression of the igfl gene, contributing to normalize circulating levels of this hormone.

Interestingly, igflr was overexpressed in untreated $\mathrm{Hz}$ mice liver, and IGF-1 replacement therapy reduced igflr expression to similar values to those found in the control group (WT) (Fig. 2b). This finding prompted us to study the expression of genes involved in IGF-1 intracellular signals (Table 1, Supplementary Table 1). RT-qPCR analysis confirmed that expression of fos, jun, and grb2 genes was reduced in untreated $\mathrm{Hz}$ mice as compared to controls (WT group), whereas IGF-1 treatment normalized the expression of these genes (Fig. 3a-c). However, nras gene was found slightly increased, while IGF-1 therapy induced a significant reduction of its expression (Fig. 3d).

Additionally, findings from the histopathological study may suggest some degree of inflammation in the IGF-1deficient mice (Hz group).
Hepatic gene expression of inflammatory and acute phase response proteins

Despite that none of the groups received inflammatory or oxidative injury, the $\mathrm{Hz}$ group showed an overexpression of several genes that encode proteins related to inflammatory and acute phase response (Table 1, Supplementary Table 2), confirmed by qRT-PCR. A significant increase in the expression of the genes clqa, ccr5, csflr, il10rb, ly96, saal, and spp 1 was found in untreated $\mathrm{Hz}$ mice as compared to controls (WT group), while no differences were found in the expressions of $c 1 q b, c c l 6$, and lyz2. Moreover, the Hz + IGF-1 group displayed a normalized gene expression of $c c r 5, c c l 6$, illorb, csflr, saa 1, spp 1, lyz2, and ly96 (Figs. 4 and 5a-c). No change in genes related to the complement proteins ( $c l a q$ and $c l q b)$ was observed in $\mathrm{Hz}+\mathrm{IGF}-1$ animals.

In addition, a significant overexpression of aifl and apaf1 genes was found in untreated deficient mice (Hz group) as compared to both controls (WT group) and $\mathrm{Hz}+\mathrm{IGF}-1$ groups (Fig. 5d, e).

Complementarily, microarray studies also revealed a relevant overexpression of genes encoding acute-phase proteins (such as macrophage activation 2 like, orosomucoid 1 and 2, calgranulin A and B, etc.) as well as HLA class II genes. These findings deserve further studies for better understanding of their impact role in IGF-1 deficiency within the liver.

\section{Liver expression of genes encoding for cytoskeleton and tight and adherent junctions and desmosomes}

Table 1 (Supplementary Table 3 ) summarizes the microarray results, showing the expression of genes encoding cytoskeletal proteins. Some of these genes were selected for RT-qPCR analysis (actb, mark2, myolb, spna2, stk11, $t u b b 2 a, v c l$, and vim). It was found that IGF-1-deficient mice (Hz group) exhibited a reduction of liver-expressed genes coding for tubulin $\beta 2 \mathrm{a}$, actin $\beta$, MAP-microtubule affinity-regulating kinase 2 , vinculin, and espectrin $\alpha 2$
Fig. 2 Real-Time qPCR analysis of a IGF-1 (igfl) and b IGF-1 receptor (igflr) gene expression from liver homogenate in the three experimental groups. ${ }^{*} p<0.05 \mathrm{~Hz}$ group vs. controls (WT); ${ }^{\circledR} p<0.05$ IGF-1 treated Hz group (Hz + IGF-1) vs. untreated $\mathrm{Hz}$ group (Hz); $p=\mathrm{ns} \mathrm{Hz}+\mathrm{IGF}-1$ vs. controls
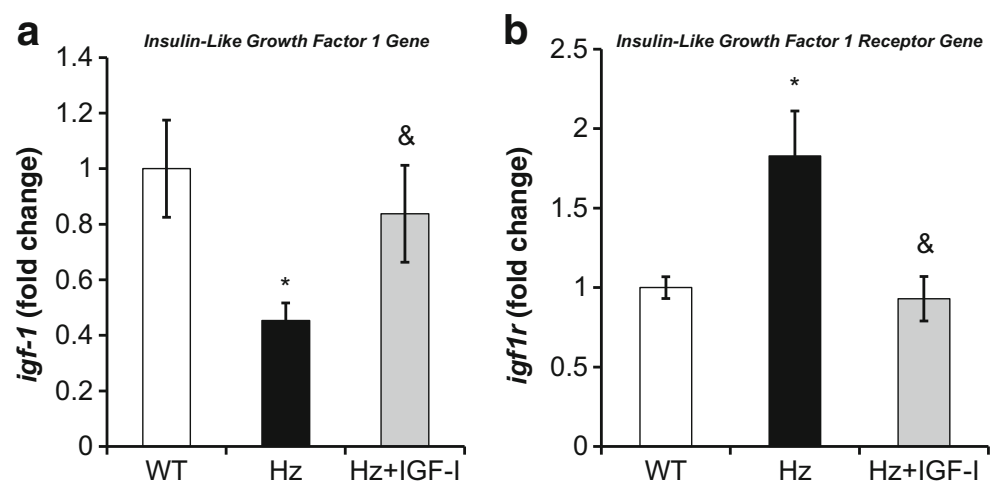
Table 1 Microarray significant results shown in fold change with $p$ values

\begin{tabular}{|c|c|c|c|c|c|}
\hline Protein & Gene & $\begin{array}{l}\text { Hz vs WT } \\
\text { (fold change) }\end{array}$ & $P$ value & $\begin{array}{l}\mathrm{Hz}+\mathrm{IGF}-1 \text { vs } \\
\mathrm{Hz} \text { (fold change) }\end{array}$ & $P$ value \\
\hline \multicolumn{6}{|l|}{ IGF-1R and Intracellular signaling } \\
\hline Insulin-like growth factor 1 receptor & $i g f l r$ & 1.44 & 0.0001 & 1.29 & 0.001 \\
\hline Neuroblastoma ras oncogene & nras & 1.53 & 0.0004 & -1.08 & 0.001 \\
\hline Jun oncogene & jun & -2.03 & 0.0006 & 1.05 & 0.01 \\
\hline FBJ osteosarcoma oncogene & fos & -1.44 & 0.001 & -1.16 & 0.13 \\
\hline \multicolumn{6}{|l|}{ Inflammation and apoptosis } \\
\hline Chemokine (C-C motif) receptor 5 & $\operatorname{ccr} 5$ & 4.38 & 0.0001 & -4.87 & 0.0001 \\
\hline Chemokine (C-C motif) ligand 6 & ccl6 & 4.34 & 0.0002 & -4.02 & 0.0001 \\
\hline Colony stimulating factor 1 receptor & $\operatorname{csflr}$ & 2.49 & 0.0004 & -2.41 & 0.0006 \\
\hline Complement component 1, q subcomponent, $\alpha \mathrm{p}$ & $c l q a$ & 5.40 & 0.0002 & -3.43 & 0.0006 \\
\hline Lysozyme 2 & $l y z 2$ & 2.99 & 0.0019 & -2.31 & 0.004 \\
\hline Lymphocyte antigen 96 & ly96 & 1.71 & 0.003 & -1.38 & 0.04 \\
\hline Interleukin 10 receptor beta & $i l 10 r b$ & 1.75 & 0.004 & -1.80 & 0.004 \\
\hline Serum amyloid A 1 & saal & 3.74 & 0.0004 & -1.70 & 0.006 \\
\hline Secreted phosphoprotein 1 & sppl & 2.44 & 0.001 & -1.80 & 0.005 \\
\hline Allograft inflammatory factor 1 & aif1 & 1.95 & 0.0001 & -2.82 & 0.00006 \\
\hline Apoptotic peptidase activating factor 1 & apaf & 1.05 & 0.05 & -1.05 & 0.05 \\
\hline \multicolumn{6}{|l|}{ Cytoskeleton } \\
\hline Tubulin, beta $2 \mathrm{~A}$ & $t u b b 2 a$ & -2.49 & 0.001 & 1.56 & 0.002 \\
\hline Vinculin & $v c l$ & -1.49 & 0.003 & 1.31 & 0.06 \\
\hline MAP/microtubule affinity-regulating kinase 2 & mark2 & -1.52 & 0.01 & 1.34 & 0.05 \\
\hline Actin, beta & $a c t b$ & 1.65 & 0.0006 & -1.58 & 0.0001 \\
\hline Serine/threonine kinase 11 & stk11 & -1.38 & 0.019 & 1.36 & 0.05 \\
\hline Myosin IB & myolb & 1.43 & 0.05 & -1.37 & 0.03 \\
\hline \multicolumn{6}{|l|}{ Intercellular junctions } \\
\hline Claudin 1 & $\operatorname{cldn} 1$ & -1.04 & 0.21 & -1.23 & 0.18 \\
\hline Claudin 7 & cldn 7 & 1.48 & 0.003 & -1.15 & 0.12 \\
\hline Claudin 14 & cldn14 & 2.37 & 0.0006 & -1.78 & 0.0003 \\
\hline Junction adhesion molecule 2 & Jam2 & 1.23 & 0.03 & -1.60 & 0.006 \\
\hline Cadherin 5 & $c d h 5$ & 1.70 & 0.0006 & -1.80 & 0.0001 \\
\hline Desmocollin 2 & $d s c 2$ & 1.46 & 0.003 & -1.46 & 0.001 \\
\hline \multicolumn{6}{|l|}{ Extracellular matrix } \\
\hline Integrin beta 2 & itgb2 & -2.46 & 0.0006 & 2.03 & 0.0001 \\
\hline Connective tissue growth factor & ctgf/bp8 & -1.60 & 0.001 & -1.57 & 0.006 \\
\hline Proteoglycan 4 & prg4 & 2.21 & 0.006 & -2.24 & 0.0001 \\
\hline Collagen, type I, alpha 2 & colla2 & -1.58 & 0.001 & 1.13 & 0.02 \\
\hline Collagen, type III, alpha 1 & $\operatorname{col} 3 \mathrm{a} 1$ & -1.71 & 0.0003 & 1.08 & 0.38 \\
\hline Collagen, type V, alpha 2 & $\operatorname{col} 5 \mathrm{a} 2$ & 1.66 & 0.0001 & -3.99 & 0.0006 \\
\hline Fibronectin 1 & fn1 & 1.50 & 0.005 & -1.45 & 0.003 \\
\hline
\end{tabular}

and a significant increase in myosin IB and vimentin genes. All the above mentioned genes were normalized in the $\mathrm{Hz}+$ IGF-1 group (Fig. 6), with the only exception of spna2, where IGF-1 treatment did not modulate at all the expression of this gene.

On the other hand, Table 1 (Supplementary Table 4) summarizes microarray findings regarding genes encoding for tight, adherent, and gap junctions and desmosomes. RT-qPCR analysis confirmed a significant overexpression as compared to WT group of genes encoding claudins 1, 7, and 14; cadherin 5; desmocollin 2; and jam 2. All of such were normalized by IGF-1 therapy $(\mathrm{Hz}+\mathrm{IGF}-1$ group) (Fig. 7a-e), with the only exception of desmocollin 2 gene (Fig. 7f). 
Fig. 3 Real-time qPCR genetic expression analysis of intracellular signaling pathways of IGF-1 receptor: a Jun oncogene (jun), b FBJ osteosarcoma oncogene (fos), $\mathbf{c}$ growth factor regulator bound protein 2 ( $g r b 2)$, and $\mathbf{d}$ neuroblastoma Ras oncogene (nras) from liver homogenate in the three experimental groups. $* p<0.05, * * p<0.01 \mathrm{~Hz}$ group vs. controls (WT); ${ }^{\&} p<0.05$, $\& \& p<0.01 \mathrm{~Hz}+\mathrm{IGF}-1$ group vs. untreated $\mathrm{Hz}$ group $(\mathrm{Hz})$; in all cases, $p=$ ns between Hz + IGF-1 and control groups
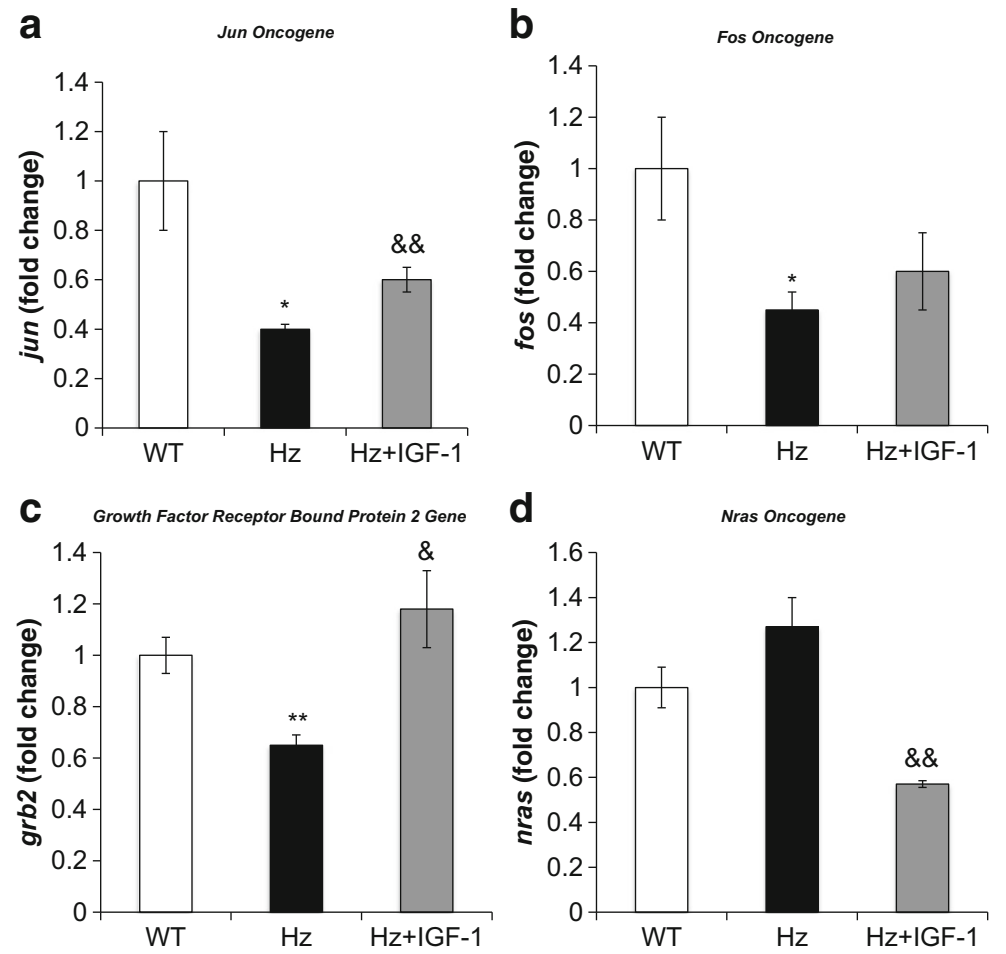

Hepatic expression of genes related to proteins of extracellular matrix and growth factors involved in ECM establishment

Microarray analysis showed an abnormal underexpression or overexpression of genes encoding extracellular matrix (ECM) or growth factors involved in the ECM establishment (Fig. 8a). Collagen 1a2, collagen 3a1, integrin $\beta 2$, and connective tissue growth factor ( $\operatorname{ctg} f / i g f b p 8)$ genes were found underexpressed in deficient IGF-1 mice (Hz group), whereas genes for collagen $5 \mathrm{a} 2$, fibronectin 1 , proteoglycan 4 , or hyaluronan 2 seemed to be overexpressed. Interestingly, all these genes from the $\mathrm{Hz}+\mathrm{IGF}-1$ group showed values similar to those found in controls (WT group), with the only exception of connective tissue growth factor (Fig. 8b, c).

\section{Hepatic oxidative damage}

In order to gain more insight into the mechanism involved in the histological damage found in IGF-1-deficient mice, hepatic levels of MDA, as a marker of lipid peroxidation, were determined. It was observed that untreated IGF-1-deficient mice (Hz group) had significantly increased levels of hepatic MDA $(5.28 \pm 1.04 \mu \mathrm{M})$ as compared to controls (WT group; $1.75 \pm 0.54 \mu \mathrm{M} ; p<0.05)$, whereas IGF-1 replacement therapy was able to significantly reduce liver oxidative damage (Hz + IGF-1; $0.96 \pm 0.55 \mu \mathrm{M} ; p<0.05$ vs. Hz and not significant vs. WT group).

\section{Discussion}

Results in this paper clearly show that the mere IGF-1 partial deficiency is associated with relevant alterations of the hepatic architecture, paired with an altered expression pattern of genes encoding cytoskeleton proteins, as well as genes related to hepatocyte polarity, cell junctions, and extracellular matrix proteins. These findings strongly suggest that IGF-1 deficiency results in profound modifications of gene expression patterns.

In addition, the single IGF-1 partial deficiency-without exogenous insults - induced the hepatic expression of the gene coding for IGF-1 receptor and a remarkable response of acute-phase proteins, inflammation, and hepatic oxidative damage. However, further studies on IGF-1R translocation to the membrane and degradation rates should be assessed to conclude its functionality and availability.

\section{Experimental model of IGF-1 deficiency and dose selected for replacement therapy}

The present work falls within a series of studies using an experimental model of haploinsufficiency, in which mice hypoexpressing igfl gene (igf1 $1^{+/}, \mathrm{Hz}$; heterozygous group) show low circulating IGF-1 levels [10, 11, 24]. The preference for IGF-1 treatment at low doses was chosen following the experience acquired from previous studies belonging to the same model [4-6, 8, 9, 11, 13, 14, 18, 21, 24, 35, 39, 40, 45]. Briefly, such dosage is enough to restore normal 
Fig. 4 Real-time qPCR genetic expression analysis of proteins involved in inflammation: a chemokine (C-C motif) receptor 5 (ccr5); b chemokine (C-C motif) ligand 6 ( $\mathrm{ccl}$ ); ; colony stimulating factor 1 receptor (csflr); d complement component 1, q subcomponent, alpha polypeptide (clqa); e lysozyme 2 (lyz2); and $\mathbf{f}$ lymphocyte antigen 96 (ly96) from liver homogenate in the three experimental groups. $*_{p}<0.05, * * p<0.01$ untreated Hz vs. controls; ${ }^{\&} p<0.05 \mathrm{~Hz}+$ IGF-1 group vs. untreated $\mathrm{Hz}$ group $(\mathrm{Hz})$; in all cases, no statistical difference between $\mathrm{Hz}+\mathrm{IGF}-1$ and control groups
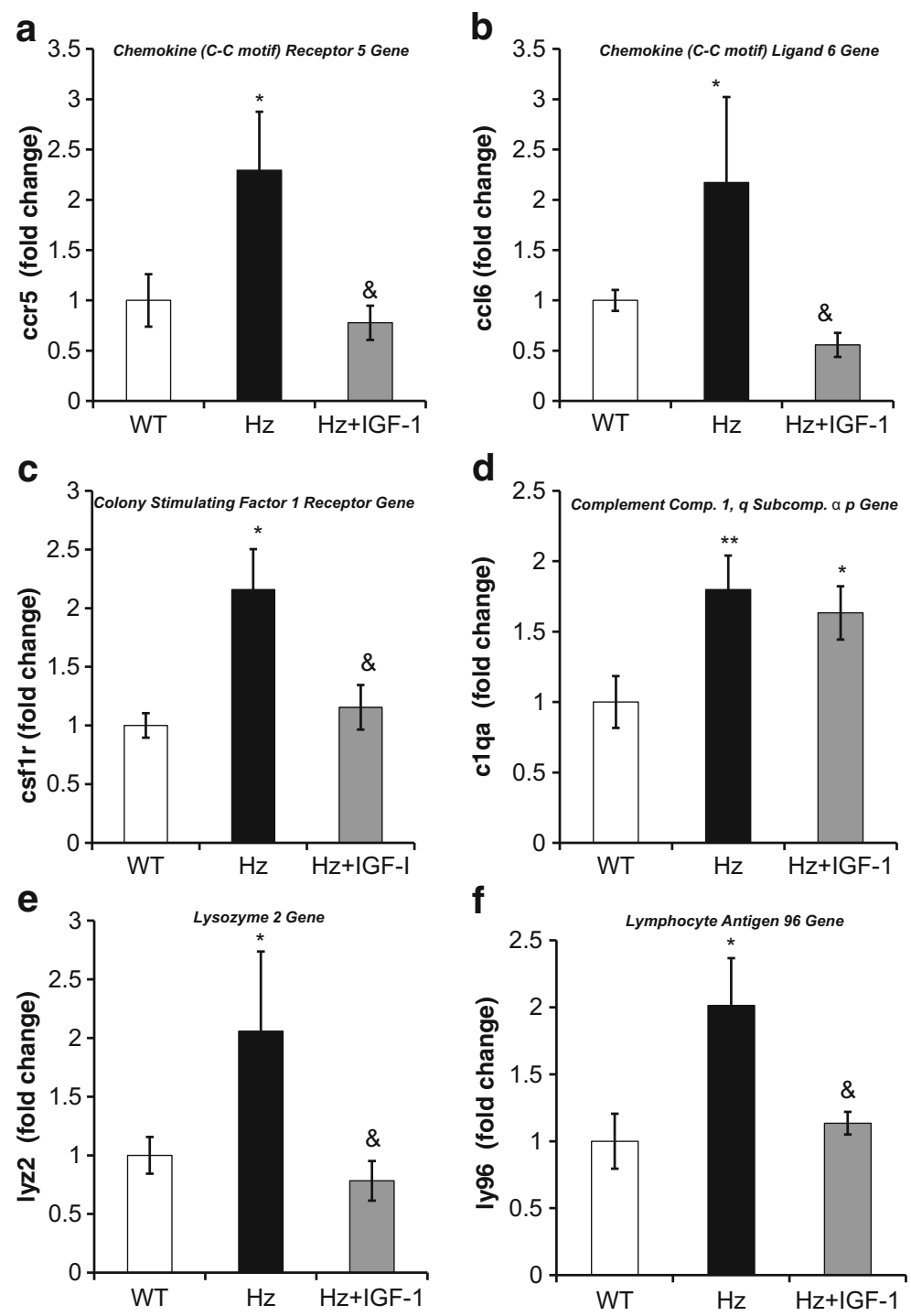

circulating IGF-1 values without inducing hypoglycemia and any adverse effects.

As previously reported in this experimental model $[10,11$, $18,24]$, the body weight of IGF-1-deficient mice was significantly lower than of their wild-type counterparts, and substitutive treatment corrected such deficiency. However, although absolute liver weight also exhibited differences in the same sense, and liver weight relative to total body weight was not different among experimental groups. Therefore, the liver was proportional to the animal size. These findings sound coherent since IGF-1 is the executioner growth factor of GH, being the most powerful anabolic hormone in mammals.

\section{Relevant response of acute-phase and inflammation proteins resulting to oxidative damage and histopathology}

A surprising response of acute-phase proteins (macrophage activation 2 like, orosomucoid 1 and 2, calgranulin 1 and 2, etc.), as well as genes encoding HLA-class II antigens, involved in the antigen-presentation, starting the cellular and humoral immunological response, resulting in inflammation. This finding requires further procedures in order to gain more insight into the impact of IGF-1 deficiency on such hepatic routes [44].

Among the genes associated with inflammation, the aif1 and apaf1 genes were included in this study, which code for allograft inflammatory factor 1 and apoptotic peptidase activator factor 1 [20]. Although apoptotic pathways were included in this study, these factors deserve specific attention. APAF-1, a well-recognized player of the apoptotic pathway, which underlies the activation of caspase-9, also seems to be involved in cell differentiation and the regulation of cell cycle in response to DNA-damaging agents, while AIF, a caspaseindependent cell death effector, is involved in the control of adipocyte differentiation and mitochondrial metabolism regulation [20]. Surprisingly, both of these proteins showed 
Fig. 5 Real-time qPCR genetic expression analysis of proteins involved in inflammation and apoptosis: a interleukin 10 receptor B (illorb), b serum amyloid A1 (saal), c secreted phosphoprotein 1 (sppl), d allograft inflammatory factor 1 (aif1), and e apoptotic peptidase activating factor 1 (apafl) from liver homogenate in the three experimental groups. $* p<0.05$, $* * p<0.01$ untreated $\mathrm{Hz}$ vs. controls; ${ }^{\&} p<0.05 \mathrm{~Hz}+$ IGF-1 group vs. untreated $\mathrm{Hz}$ group $(\mathrm{Hz})$; in all cases, no statistical difference between $\mathrm{Hz}+\mathrm{IGF}-1$ and control groups
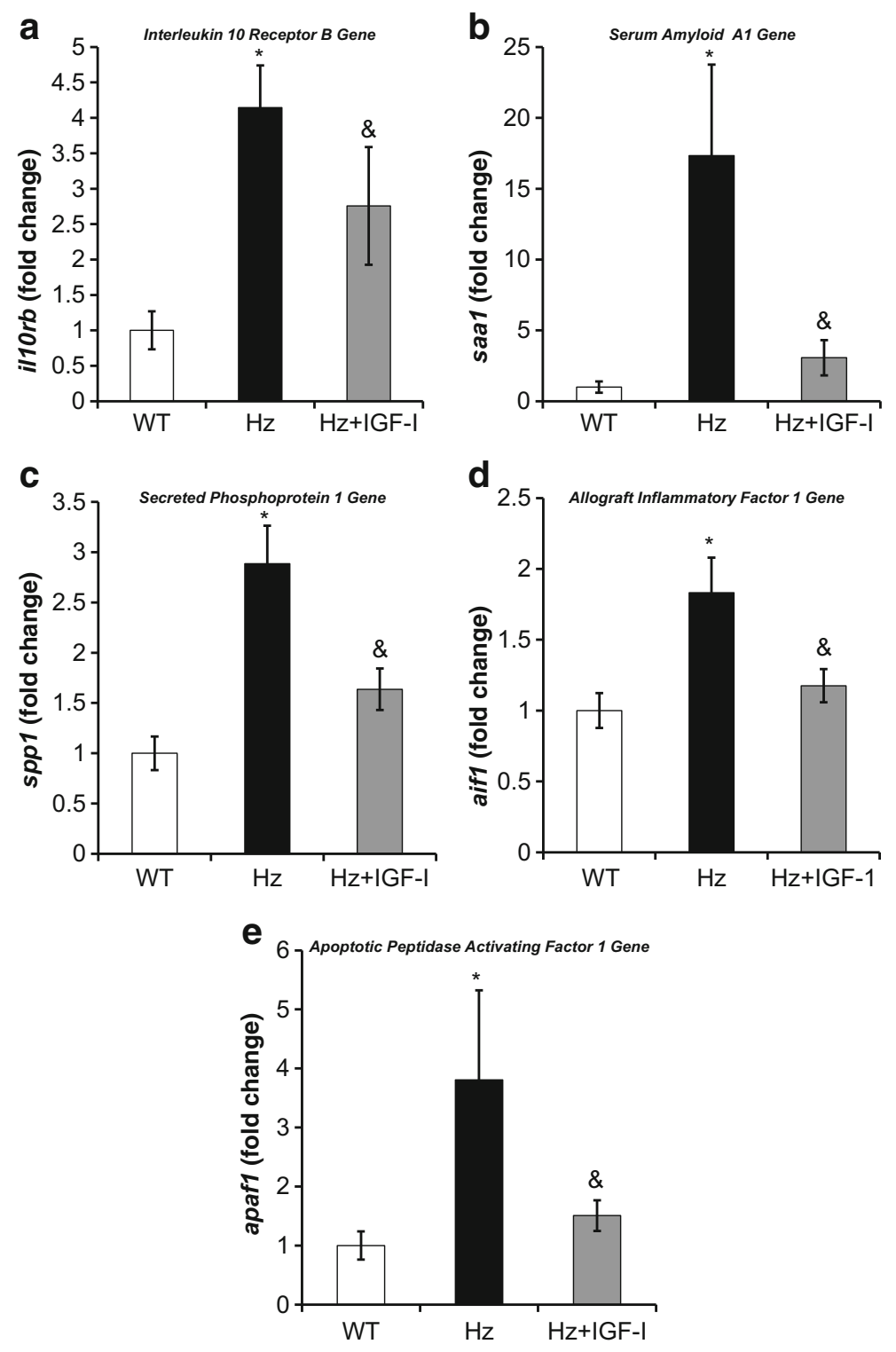

definitive overexpression in untreated $\mathrm{Hz}$ mice, and substitutive treatment reversed such expression to normal values. This could mechanistically indicate that intrinsic apoptotic pathways were overreacting, even with no harm to the animal. Such finding could be explained by altered hepatic architecture and concomitant cessation of survival signals that adhesion molecules transmit when appropriately attached (anoikis).

Another result that deserves special mention is the altered expression of genes encoding cytoskeletal proteins. In hepatocytes, epithelial cell differentiation generates basal lamina membrane at cell-cell contact sites (bile canaliculi) orientating microtubules to aim the proper polarization of the cell [16].

Untreated $\mathrm{Hz}$ mice showed a significant reduction of two genes implicated in microtubule structure and stability: tubulin $\beta 2 \mathrm{~A}$ and MAP/microtubule affinity-regulating kinase 2 .
Of interest, treatment was effective as no differences were found between controls and the IGF-1 treated $\mathrm{Hz}$ group (Fig. 6a, c). Such finding might explain the aberrant histological observations in untreated $\mathrm{Hz}$ mice, which suggested an altered hepatocyte polarity.

\section{The mere IGF-1 deficiency makes the liver a target organ for IGF-1}

One of the major findings of this paper is the association between the partial IGF-1 deficiency and the significant expression of IGF-1, the receptor in the liver, suggesting that IGF-1 contributes to the liver homeostasis. The lack of expression of the IGF-1 receptor in animals that have not received any injury seems to mean that it is a "defense mechanism," as previous results suggested [4, 21, 35, 40, 41, 45]. Such 
Fig. 6 Real-time qPCR genetic expression analysis of proteins involved in the cytoskeleton: a tubulin beta 2 Alpha (tubb2a), b vinculin $(v c l), \mathbf{c}$ MAP/

microtubule affinity-regulating kinase 2 (mark2), $\mathbf{d}$ actin beta ( $a c t b)$, e serine/threonine kinase 11 (stk11), and $\mathbf{f}$ myosin 1 beta (myolb) from liver homogenate in the three experimental groups. ${ }^{*} p<0.05, * * p<0.01 \mathrm{~Hz}$ group vs. controls (WT); ${ }^{\&} p<0.05$, $\& \& p<0.01 \mathrm{~Hz}+\mathrm{IGF}-1$ group vs. untreated $\mathrm{Hz}$ group $(\mathrm{Hz})$; in all cases, no statistical difference between $\mathrm{Hz}+\mathrm{IGF}-1$ and control groups
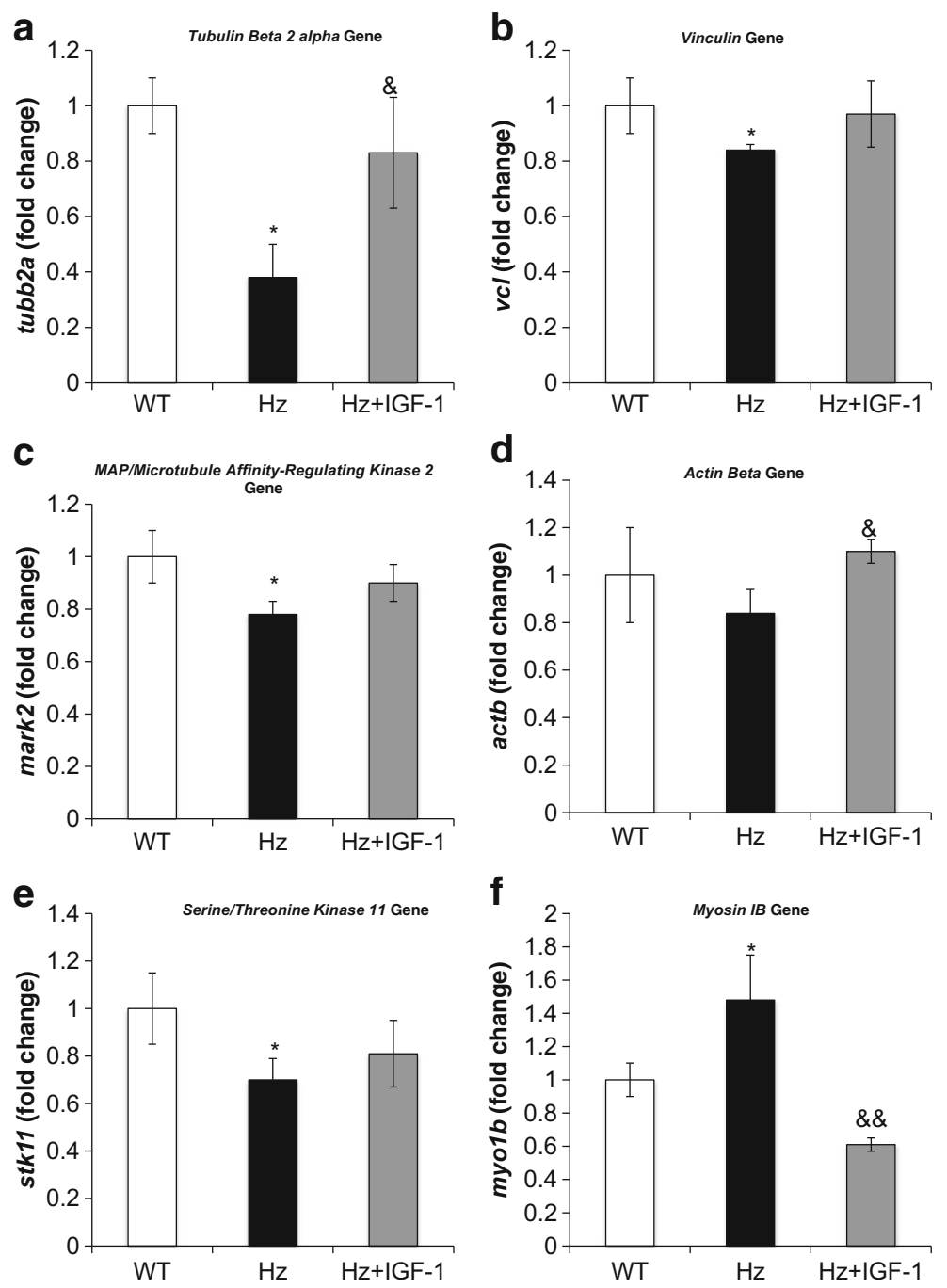

defense mechanism allows the liver to take advantage of the beneficial actions of this hormone following injury. In spite, this study shows how mere IGF-1 deficiency acts as "harmful agent" altering cytoskeletal components and normal ECM establishment, modifying expression of genes showing a genetic pattern of inflammation and oxidative stress with a relevant response of acute-phase proteins.

A direct effect of IGF-1 on the liver is an astonishing novel concept in hepatology, since until now, it has been recognized that the liver is not a target organ for IGF-1, supported by the absence of its receptor in liver cells under physiological conditions $[3,33,34,50]$. However, in the last decades, accumulated evidence have suggested that a damaged liver must be expressing the IGF-1 receptor since short cycles of low doses of IGF-1 induced many beneficial effects on the hepatic parenchyma and function $[4,17,21,35,40,45]$.

The autocrine regulation of IGF-1 was first demonstrated by Caro et al. in 1988 [3]. The diverse activities of IGF-1 in stimulating mitogenesis, increasing substrate uptake and metabolic activity, inhibiting apoptosis, and modulating a variety of specific functions in highly differentiated cell types are, in most part, mediated through binding and activation of the type I IGF1 receptor. Generally, the interaction of an IGFBP with IGF-1 blocks the receptor activation and thus its effects at all levels $[1,36]$. Perhaps, this could be one of the mechanisms behind our findings regarding overexpression of igflr and hypoexpression of $i g f b p 1, i g f b p 2$, and $i g f b p 5$ [18] and $i g f b p 8$. In turn, this decrease in function could also explain the observed changes in liver cellular architecture, the proinflammatory profile found, and even the intracellular derangements observed.

On the other hand, overexpressed igflr, which under physiological conditions is virtually absent in hepatic parenchymal cells in adult rats, mice, and humans, induced important changes in intracellular signaling pathways [3, 34].

Under normal conditions, once IGF-1 binds to its receptor and activates intracellular signaling, IRS- 1 with the concourse of PI3K, Shp2, Grb2, and Sos activate Shc, which in turn activates Ras. The Ras pathway is a prominent signaling pathway for cell proliferation and survival [19]. 
Fig. 7 Real-time qPCR genetic expression analysis of proteins implicated in intercellular junctions: a claudin 1 (cldn1), b claudin 7 ( $c l d n 7)$, c claudin 14 (cldn14), d junction adhesion molecule 2 (jam2), e cadherin 5 (cdh5), and $\mathbf{f}$ desmocollin 2 (dsc2) from liver homogenate in the three experimental groups. $* p<0.05, * * p<0.01 \mathrm{~Hz}$ group vs. controls (WT); ${ }^{\&} p<0.05$, $\& \& p<0.01 \mathrm{~Hz}+\mathrm{IGF}-1$ group vs. untreated $\mathrm{Hz}$ group $(\mathrm{Hz})$; in all cases, no statistical difference between $\mathrm{Hz}+\mathrm{IGF}-1$ and control groups
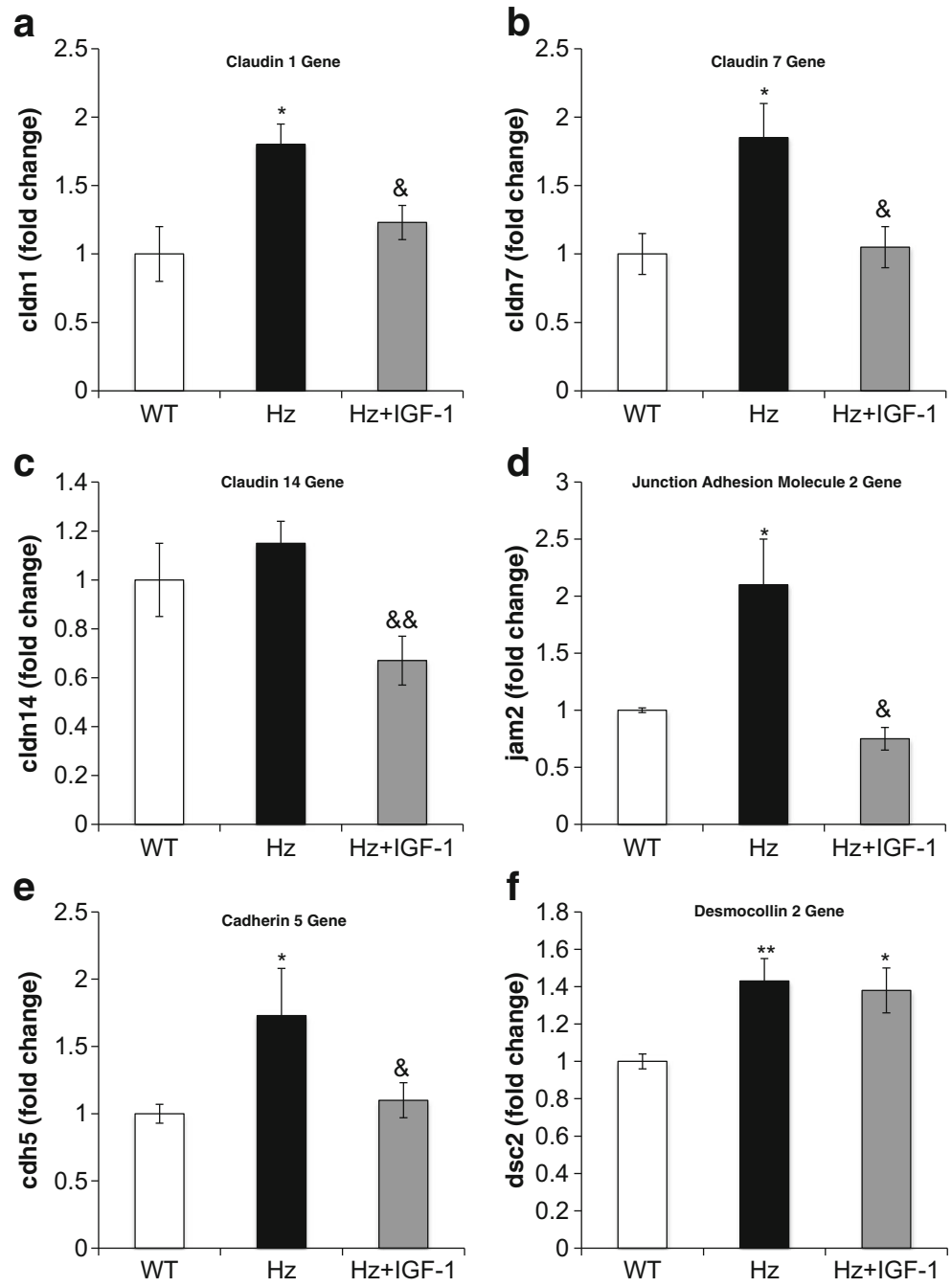

IGF-1 deficiency in our $\mathrm{Hz}$ mouse model resulted in overexpression of igflr and nras and downregulation of grb2 by unknown mechanism(s). We may speculate that the sole overexpression of igflr could have triggered an aberrant activation of nras. Under normal conditions, nras and its analogs hras, rras, and kras activate the MAPK

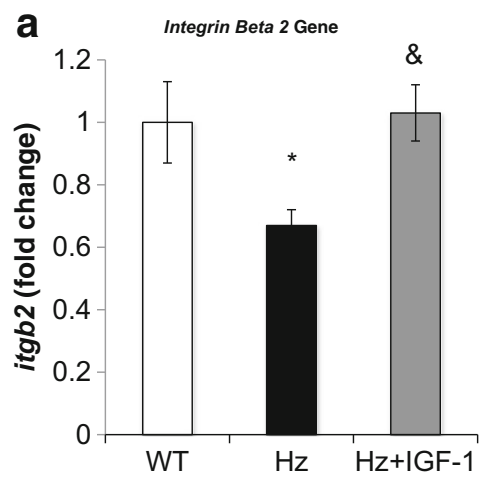

Fig. 8 Real-time qPCR genetic expression analysis of proteins implicated in extracellular matrix: a integrin beta 2 (itgb2) and b connective tissue growth factor ( $\operatorname{ctgf/igfbp8)}$ from liver homogenate in the three experimental groups. $* p<0.05, * * p<0.01, * * * p<0.001 \mathrm{~Hz}$

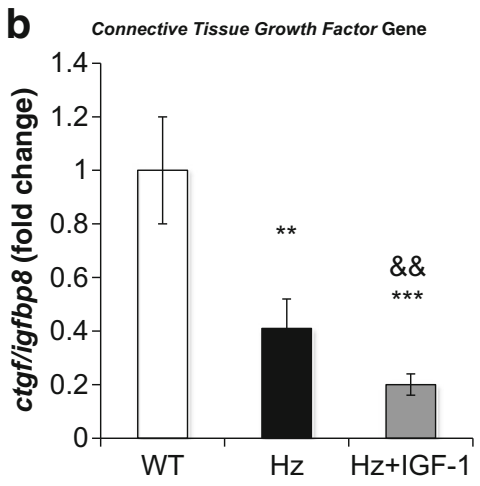

group vs. controls (WT); ${ }^{\&} p<0.05,{ }^{\& \&} p<0.01 \mathrm{~Hz}+$ IGF-1 group vs. untreated $\mathrm{Hz}$ group $(\mathrm{Hz})$; in all cases, no statistical difference between $\mathrm{Hz}+\mathrm{IGF}-1$ and control groups 
pathway, which in turn, together with erk, exerts intranuclear effects on elk-1, which aided with ap-1 activates $c f o s$ and cjun. All these genes downstream regulate the expression of genes involved in cell proliferation and survival and are key participants in anoikis, a special form of apoptosis triggered by the loss of cell-cell or cellmatrix anchorage [23].

Perhaps as a result of nras overexpression, mapk1 was also overregulated in microarray studies, although below the established threshold to include it in the RT-qPCR panel. Unexpectedly, fos and jun were underregulated, probably as an autoprotective mechanism developed by the liver cells to avoid death. It would be helpful to further explore elk-1 and ap-1. Interestingly, substitutive treatment normalized the expression of igfl, igflr, grb2, and nras, while no differences in fos or jun were observed (Fig. 3a, b).

In this sense, the reduction of igfbp 8 may deserve a particular mention because it has included a domain for connective tissue growth factor (CTGF). This molecule is a multimodular protein that resides in the extracellular matrix, which binds and coordinates biologically active factors involved in ECM establishment under physiological conditions $[11,37]$. CTGF has its own IGF-1 recognition domain (thus acting also as IGFBP-8), suggesting a role for IGF-1 deficiency in TGF $\beta$ activation (a wellknown collagen production stimulator) [46]. In this study, the partial IGF-1 deficiency was associated to $\operatorname{ctg} f$ (or igfbp 8 ) gene underexpression and thus suggesting an altered ECM establishment, in accordance with previous findings on testicle using this same experimental model [11]. Although IGF-1 therapy did not increase $\operatorname{ctg} f$ expression in the liver, it did show effectiveness on testes [11].

\section{Conclusions}

In conclusion, partial IGF-1 deficiency leads to liver expression of genes encoding IGF-1 receptor and numerous proteins involved in acute-phase and inflammation responses, resulting in liver oxidative damage. This response resembles that of a pathological liver, which typically shows altered expression of genes related to cytoskeletal proteins, hepatocyte polarity, cell junctions, and extracellular matrix proteins as occurs in these animal's livers.

Acknowledgments The authors would like to express their gratitude to Prof. A. Efstratiadis (Columbia University, College of Physicians and Surgeons, New York, USA) for kindly providing the transgenic IGF-1 mice and to Chiron Company (Emeryville, CA) for granting the recombinant human IGF-1 used in this study. A very special thank to Ms. Susana Arahuetes, Ms. Paloma Fernandez, and Ms. Isabel Sánchez Cruz for their expert technical assistance. We are also very grateful to
Karl Steinmetz for the English revision of the manuscript and Jesús Ortiz Urbina and Tomás Lankenau for his invaluable help.

\section{Compliance with ethical standards}

Conflict of interest The authors declare that they have no conflicts of interest.

Open Access This article is distributed under the terms of the Creative Commons Attribution 4.0 International License (http:// creativecommons.org/licenses/by/4.0/), which permits unrestricted use, distribution, and reproduction in any medium, provided you give appropriate credit to the original author(s) and the source, provide a link to the Creative Commons license, and indicate if changes were made.

\section{References}

1. Baxter RC (2000) Insulin-like growth factor (IGF)-binding proteins: interactions with IGFs and intrinsic bioactivities. Am J Phys Endocrinol Metab 278:E967-E976

2. Berelowitz M, Szabo M, Frohman LA, Firestone S, Chu L, Hintz RL (1981) Somatomedin-C mediates growth hormone negative feedback by effects on both the hypothalamus and the pituitary. Science 212:1279-1281

3. Caro JF, Poulos J, Ittoop O, Pories WJ, Flickinger EG, Sinha MK (1988) Insulin-like growth factor I binding in hepatocytes from human liver, human hepatoma, and normal, regenerating, and fetal rat liver. J Clin Invest 81:976-981

4. Castilla-Cortazar I, Garcia M, Muguerza B, Quiroga J, Perez R, Santidrian S, Prieto J (1997) Hepatoprotective effects of insulinlike growth factor I in rats with carbon tetrachloride-induced cirrhosis. Gastroenterology 113:1682-1691

5. Castilla-Cortazar I, Prieto J, Urdaneta E, Pascual M, Nunez M, Zudaire E, Garcia M, Quiroga J, Santidrian S (1997) Impaired intestinal sugar transport in cirrhotic rats: correction by low doses of insulin-like growth factor I. Gastroenterology 113:1180-1187

6. Castilla-Cortazar I, Garcia M, Quiroga J, Diez N, Diez-Caballero F, Calvo A, Diaz M, Prieto J (2000) Insulin-like growth factor-I reverts testicular atrophy in rats with advanced cirrhosis. Hepatology 31:592-600

7. Castilla-Cortazar I, Aliaga-Montilla MA, Salvador J, Garcia M, Delgado G, Gonzalez-Baron S, Quiroga J, Prieto J (2001) Insulinlike growth factor-I restores the reduced somatostatinergic tone controlling growth hormone secretion in cirrhotic rats. Liver 21: 405-409

8. Castilla-Cortazar I, Diez N, Garcia-Fernandez M, Puche JE, DiezCaballero F, Quiroga J, Diaz-Sanchez M, Castilla A, Casares AD, Varela-Nieto I et al (2004) Hematotesticular barrier is altered from early stages of liver cirrhosis: effect of insulin-like growth factor 1 . World journal of gastroenterology : WJG 10:2529-2534

9. Castilla-Cortazar I, Pascual M, Urdaneta E, Pardo J, Puche JE, Vivas B, Diaz-Casares A, Garcia M, Diaz-Sanchez M, VarelaNieto I et al (2004) Jejunal microvilli atrophy and reduced nutrient transport in rats with advanced liver cirrhosis: improvement by insulin-like growth factor I. BMC Gastroenterol 4:12

10. Castilla-Cortazar I, Guerra L, Puche JE, Munoz U, Barhoum R, Escudero E, Lavandera JL (2014) An experimental model of partial insulin-like growth factor-1 deficiency in mice. J Physiol Biochem 70:129-139

11. Castilla-Cortazar I, Gago A, Munoz U, Avila-Gallego E, GuerraMenendez L, Sadaba MC, Garcia-Magarino M, Olleros SantosRuiz M, Aguirre GA \& Puche JE (2015) Mechanisms underlying 
testicular damage and dysfunction in mice with partial IGF-1 deficiency and the effectiveness of IGF-1 replacement therapy. Urology

12. Caufriez A, Reding P, Urbain D, Golstein J, Copinschi G (1991) Insulin-like growth factor I: a good indicator of functional hepatocellular capacity in alcoholic liver cirrhosis. J Endocrinol Investig $14: 317-321$

13. Cemborain A, Castilla-Cortazar I, Garcia M, Quiroga J, Muguerza B, Picardi A, Santidrian S, Prieto J (1998) Osteopenia in rats with liver cirrhosis: beneficial effects of IGF-I treatment. J Hepatol 28: 122-131

14. Cemborain A, Castilla-Cortazar I, Garcia M, Muguerza B, Delgado G, Diaz-Sanchez M, Picardi A (2000) Effects of IGF-I treatment on osteopenia in rats with advanced liver cirrhosis. J Physiol Biochem 56:91-99

15. Clemmons DR, Busby W, Clarke JB, Parker A, Duan C \& Nam TJ (1998) Modifications of insulin-like growth factor binding proteins and their role in controlling IGF actions. Endocrine J 45(Suppl:S1-8)

16. Cohen D, Brennwald PJ, Rodriguez-Boulan E, Musch A (2004) Mammalian PAR-1 determines epithelial lumen polarity by organizing the microtubule cytoskeleton. J Cell Biol 164:717-727

17. Conchillo M, de Knegt RJ, Payeras M, Quiroga J, Sangro B, Herrero JI, Castilla-Cortazar I, Frystyk J, Flyvbjerg A, Yoshizawa $\mathrm{C}$ et al (2005) Insulin-like growth factor I (IGF-I) replacement therapy increases albumin concentration in liver cirrhosis: results of a pilot randomized controlled clinical trial. J Hepatol 43:630-636

18. De Ita JR, Castilla-Cortazar I, Aguirre GA, Sanchez-Yago C, Santos-Ruiz MO, Guerra-Menendez L, Martin-Estal I, GarciaMagarino M, Lara-Diaz VJ, Puche JE et al (2015) Altered liver expression of genes involved in lipid and glucose metabolism in mice with partial IGF-1 deficiency: an experimental approach to metabolic syndrome. J Transl Med 13:326

19. Dhillon AS, Hagan S, Rath O, Kolch W (2007) MAP kinase signalling pathways in cancer. Oncogene 26:3279-3290

20. Galluzzi L, Kepp O, Trojel-Hansen C, Kroemer G (2012) Nonapoptotic functions of apoptosis-regulatory proteins. EMBO Rep $13: 322-330$

21. Garcia-Fernandez M, Castilla-Cortazar I, Diaz-Sanchez M, Navarro I, Puche JE, Castilla A, Casares AD, Clavijo E, Gonzalez-Baron S (2005) Antioxidant effects of insulin-like growth factor-I (IGF-I) in rats with advanced liver cirrhosis. BMC Gastroenterol 5:7

22. Garcia-Fernandez M, Delgado G, Puche JE, Gonzalez-Baron S, Castilla Cortazar I (2008) Low doses of insulin-like growth factor I improve insulin resistance, lipid metabolism, and oxidative damage in aging rats. Endocrinology 149:2433-2442

23. Grossmann J (2002) Molecular mechanisms of "detachment-induced apoptosis - anoikis". Apoptosis : an international journal on programmed cell death 7:247-260

24. Guerra-Menendez L, Sadaba MC, Puche JE, Lavandera JL, de Castro LF, de Gortazar AR, Castilla-Cortazar I (2013) IGF-I increases markers of osteoblastic activity and reduces bone resorption via osteoprotegerin and RANK-ligand. J Transl Med 11:271

25. Irizarry RA, Ooi SL, Wu Z \& Boeke JD (2003) Use of mixture models in a microarray-based screening procedure for detecting differentially represented yeast mutants. Stat Appl Genet Mol Biol 2: Article1

26. Johnson WE, Li C, Rabinovic A (2007) Adjusting batch effects in microarray expression data using empirical Bayes methods. Biostatistics 8:118-127

27. Klapper DG, Svoboda ME, Van Wyk JJ (1983) Sequence analysis of somatomedin-C: confirmation of identity with insulin-like growth factor I. Endocrinology 112:2215-2217

28. Le Roith D (1997) Seminars in medicine of the Beth Israel Deaconess Medical Center. Insulin-like growth factors. N Engl J Med 336:633-640

29. LeRoith D, Werner H, Beitner-Johnson D, Roberts CT Jr (1995) Molecular and cellular aspects of the insulin-like growth factor I receptor. Endocr Rev 16:143-163
30. Liu JP, Baker J, Perkins AS, Robertson EJ, Efstratiadis A (1993) Mice carrying null mutations of the genes encoding insulin-like growth factor I (Igf-1) and type 1 IGF receptor (Igflr). Cell 75: 59-72

31. Livak KJ, Schmittgen TD (2001) Analysis of relative gene expression data using real-time quantitative PCR and the 2(-delta delta $\mathrm{C}(\mathrm{T})$ ) method. Methods 25:402-408

32. Martin-Estal I, de la Garza R \& Castilla-Cortazar I (2015) Intrauterine growth retardation (IUGR) as a novel condition of insulin-like growth factor-1 (IGF-1) deficiency. Rev Physiol Biochem Pharmacol

33. Massague J, Blinderman LA, Czech MP (1982) The high affinity insulin receptor mediates growth stimulation in rat hepatoma cells. J Biol Chem 257:13958-13963

34. Massague J, Czech MP (1982) The subunit structures of two distinct receptors for insulin-like growth factors I and II and their relationship to the insulin receptor. J Biol Chem 257:5038-5045

35. Muguerza B, Castilla-Cortazar I, Garcia M, Quiroga J, Santidrian S, Prieto J (2001) Antifibrogenic effect in vivo of low doses of insulinlike growth factor-I in cirrhotic rats. Biochim Biophys Acta 1536: 185-195

36. Murphy LJ (1998) Insulin-like growth factor-binding proteins: functional diversity or redundancy? J Mol Endocrinol 21:97-107

37. Oliver N, Sternlicht M, Gerritsen K, Goldschmeding R (2010) Could aging human skin use a connective tissue growth factor boost to increase collagen content? The Journal of investigative dermatology 130:338-341

38. Ozdinler PH, Macklis JD (2006) IGF-I specifically enhances axon outgrowth of corticospinal motor neurons. Nat Neurosci 9:13711381

39. Pascual M, Castilla-Cortazar I, Urdaneta E, Quiroga J, Garcia M, Picardi A, Prieto J (2000) Altered intestinal transport of amino acids in cirrhotic rats: the effect of insulin-like growth factor-I. American journal of physiology Gastrointestinal and liver physiology 279: G319-G324

40. Perez R, Garcia-Fernandez M, Diaz-Sanchez M, Puche JE, Delgado G, Conchillo M, Muntane J, Castilla-Cortazar I (2008) Mitochondrial protection by low doses of insulin-like growth factor-I in experimental cirrhosis. World journal of gastroenterology: WJG 14:2731-2739

41. Pierzchala M, Pareek CS, Urbanski P, Goluch D, Kamyczek M, Rozycki M, Smoczynski R, Horbanczuk JO, Kuryl J (2012) Study of the differential transcription in liver of growth hormone receptor (GHR), insulin-like growth factors (IGF1, IGF2) and insulin-like growth factor receptor (IGF1R) genes at different postnatal developmental ages in pig breeds. Mol Biol Rep 39:30553066

42. Puche JE, Garcia-Fernandez M, Muntane J, Rioja J, GonzalezBaron S, Castilla Cortazar I (2008) Low doses of insulin-like growth factor-I induce mitochondrial protection in aging rats. Endocrinology 149:2620-2627

43. Puche JE, Castilla-Cortazar I (2012) Human conditions of insulinlike growth factor-I (IGF-I) deficiency. J Transl Med 10:224

44. Smith TJ (2010) Insulin-like growth factor-I regulation of immune function: a potential therapeutic target in autoimmune diseases? Pharmacol Rev 62:199-236

45. Tutau F, Rodriguez-Ortigosa C, Puche JE, Juanarena N, Monreal I, Garcia Fernandez M, Clavijo E, Castilla A, Castilla-Cortazar I (2009) Enhanced actions of insulin-like growth factor-I and interferon-alpha co-administration in experimental cirrhosis. Liver international : official journal of the International Association for the Study of the Liver 29:37-46

46. Verrecchia F, Mauviel A (2007) Transforming growth factor-beta and fibrosis. World journal of gastroenterology : WJG 13:30563062 
47. Woods KA, Camacho-Hubner C, Savage MO, Clark AJ (1996) Intrauterine growth retardation and postnatal growth failure associated with deletion of the insulin-like growth factor I gene. N Engl J Med 335:1363-1367

48. Wu A, Grant DB, Hambley J, Levi AJ (1974) Reduced serum somatomedin activity in patients with chronic liver disease. Clinical science and molecular medicine 47:359-366
49. Z L (1999) Laron syndrome - primary growth hormone resistance. In Hormone resistance syndromes contemporary endocrinology. Edited by Jameson JL. NJ: Humana Press 2:17-37

50. Zimmermann EM, Li L, Hoyt EC, Pucilowska JB, Lichtman S, Lund PK (2000) Cell-specific localization of insulin-like growth factor binding protein mRNAs in rat liver. American journal of physiology Gastrointestinal and liver physiology 278:G447-G457 